\title{
OPTIMASI TRANSPOR Cu(II) DENGAN APDC SEBAGAI ZAT PEMBAWA MELALUI TEKNIK MEMBRAN CAIR FASA RUAH
}

\author{
Imelda, Zaharasmi Kahar, Maria Simarmata, dan Djufri Mustafa \\ Laboratorium Elektrokimia Jurusan Kimia FMIPA UNAND
}

\begin{abstract}
The transport of $\mathrm{Cu}(\mathrm{II})$ with Ammonium Pyrrolidine Dithiocarbamate(APDC) as carrier through bulk liquid membrane had been researched. The measurement was performed to source phase and feed phase by using Atomic Absorption Spectrophotometer toward $\lambda_{\text {maks }} 324.7 \mathrm{~nm}$. The result of the research showed the optimum condition to separate $20 \mathrm{ppm}$ of $\mathrm{Cu}(\mathrm{II})$ was at $\mathrm{pH} 4$ of source phase, concentration of APDC was $1: 30$, stirring time was 2 hours, and the stirring velocity was $300 \mathrm{rpm}$ with the percentage of $\mathrm{Cu}(\mathrm{II})$ transport to feed phase was $97,06 \%$ and percentage of remains $\mathrm{Cu}(\mathrm{II})$ was $0 \%$.
\end{abstract}

Keywords : Liquid Membrane, $C u(I I)$ ion, APDC, transport

\section{PENDAHULUAN}

Proses pemisahan ion logam dari campuran dengan menggunakan membran cair telah banyak dipublikasikan. Membran cair merupakan pilihan yang dapat digunakan untuk pemisahan spesi kimia tertentu karena bersifat selektif permiabel dengan cara memanfaatkan pelarut organik atau anorganik tertentu yang berfungsi sebagai lintasan transpor dari komponen kimia yang dipisahkan ${ }^{[1]}$.

Pada penelitian ini membran cair dikembangkan ke dalam teknik membran cair fasa ruah untuk sistem pemisahan karena cara pembuatan yang mudah dan praktis. Selain itu, membran dapat didaur ulang serta proses ekstraksi dan stripping dari spesi kimia tertentu berlangsung dalam satu tahap secara kontinu sehingga memungkinkan proses ekstraksi lebih praktis $^{[2]}$.

Pemilihan $\mathrm{Cu}$ (II) sebagai fasa sumber pada penelitian ini karena $\mathrm{Cu}$ (II) merupakan salah satu logam berat yang terdapat bersama-sama logam berat lainnya di dalam limbah-limbah industri dan $\mathrm{Cu}$ (II) merupakan salah satu logam yang dapat membentuk kompleks dengan APDC. Sebelumnya pemisahan $\mathrm{Cu}$ (II) telah pernah dilakukan dengan oksin sebagai zat pembawa melalui membran cair fasa ruah tetapi belum ada yang melakukan transpor $\mathrm{Cu}$ (II) dengan APDC sebagai zat pembawa ${ }^{[3]}$. Zat pembawa berfungsi sebagai ligan yang mampu menarik ion-ion logam yang diinginkan di fasa tertentu dan mengantarkannya ke fasa lain berdasarkan perbedaan kelarutan kompleksnya pada antar muka fasa sumber dan fasa membran.

APDC sebagai pengompleks mempunyai kemampuan yang tinggi dalam berinteraksi dengan sejumlah besar ion logam pada konsentrasi rendah secara serentak ${ }^{[4]}$. Penelitian ini merupakan penelitian pendahuluan yang bertujuan untuk menentukan spesifikasi ekstraksi $\mathrm{Cu}(\mathrm{II})$ dengan APDC sebagai pengompleks melalui kondisi optimum sistem transpor $\mathrm{Cu}(\mathrm{II})$ antarfasa menggunakan teknik membran cair fasa ruah.

\section{METODOLOGI PENELITIAN}

\section{Alat dan Bahan}

Alat-alat yang digunakan pada penelitian ini adalah Spektrofotometer Serapan Atom (SSA) Younglin 1080, sel membran cair fasa ruah, Neraca Analitik Ainsworth, Magnetik Stirrer, pH meter Hanna Instruments tipe HI 8010, dan alat-alat gelas kimia lainnya. 
Bahan-bahan yang digunakan pada penelitian ini antara lain: garam $\mathrm{CuSO}_{4} .5 \mathrm{H}_{2} \mathrm{O}, \mathrm{CHCl}_{3}$, APDC, $\mathrm{HCl} 1 \mathrm{M}$ dan $0,01 \mathrm{M}, \mathrm{HNO}_{3} 1 \mathrm{M}$, $\mathrm{H}_{2} \mathrm{SO}_{4} 1 \mathrm{M}$ dan $0,1 \mathrm{M}$, larutan buffer asetat dan akuades.

\section{Pembuatan larutan fasa sumber (f.s)}

Sejumlah 3,9295 g CuSO$_{4} .5 \mathrm{H}_{2} \mathrm{O}$ dicampurkan dengan $3 \quad \mathrm{~mL}^{2} \mathrm{H}_{2} \mathrm{SO}_{4} \quad 0,1 \quad \mathrm{M}$, kemudian dilarutkan dengan akuades sampai volumenya $1000 \mathrm{~mL}$, Larutan yang diperoleh adalah larutan $\mathrm{Cu}$ (II) $1,57 \times 10^{-2} \mathrm{M}$. Diambil sebanyak $1 \mathrm{~mL}$, kemudian ditambahkan $\mathrm{HCl} 0,01 \mathrm{M}$ untuk mengatur $\mathrm{pH}$ yang diinginkan (3 - 7) dan ditambahkan larutan buffer asetat untuk menahan $\mathrm{pH}$, larutan diencerkan dengan akuades ke dalam labu ukur $50 \mathrm{~mL}$ sampai tanda batas sehingga diperoleh larutan $\mathrm{Cu}$ (II) $3,15 \times 10^{-4} \mathrm{M}$.

\section{Pembuatan larutan APDC}

Sebanyak 0,0052 g APDC dilarutkan dengan akuades hingga volumenya menjadi $100 \mathrm{~mL}$. Larutan yang diperoleh adalah larutan APDC dengan konsentrasi $3,15 \times 10^{-4} \mathrm{M}$. Untuk membuat larutan kerjanya, larutan ini dicampur dengan larutan $\mathrm{Cu}(\mathrm{II})$ dimana perbandingan $\mathrm{Cu}(\mathrm{II})$ dengan APDC yaitu 1:6, $1: 10,1: 15,1: 20,1: 30$, dan $1: 32$.

\section{Pembuatan larutan fasa membran (f.m)}

Sebanyak $30 \mathrm{~mL}$ larutan kloroform dimasukkan ke dalam beker gelas sel membran cair fasa ruah yang difungsikan sebagai fasa membran.

\section{Pembuatan Larutan Fasa penerima(f.p)}

Fasa penerima merupakan larutan dari asam kuat (asam klorida, asam sulfat, dan asam nitrat) dengan konsentrasi $1 \mathrm{M}$ sampai $5 \mathrm{M}$.

\section{Penentuan transpor $\mathrm{Cu}(\mathrm{II})$ dengan teknik membran cair fasa ruah}

Proses transpor dilakukan seperti percobaan Savafi $(1998)^{[5]}$. Disiapkan beker gelas $50 \mathrm{~mL}$ dan dimasukkan sebagai fasa membran yaitu $30 \mathrm{~mL}$ kloroform. Dalam larutan fasa membran ini dicelupkan sebuah tabung kaca silindris dan dipipetkan ke dalamnya $6 \mathrm{~mL}$ larutan fasa sumber berupa $\mathrm{Cu}$ (II) dan APDC pada $\mathrm{pH} 3$ sampai 7. Di luar tabung gelas dipipetkan $12 \mathrm{~mL}$ fasa penerima asam nitrat, asam sulfat atau asam klorida pada konsentrasi tertentu. Teknis operasi dilakukan melalui pengadukan dengan memakai magnetik stirer pada kecepatan 300 rpm selama 1 jam. Setelah pendiaman 15 menit, fasa penerima dan fasa sumber diambil untuk diukur jumlah konsentrasi ion yang terkandung di dalamnya dengan Spektrofotometer Serapan Atom pada $\lambda_{\text {maks }} 324,7 \mathrm{~nm}$.

\section{Penetapan konsentrasi ion dengan SSA}

Konsentrasi $\mathrm{Cu}$ (II) di dalam fasa sumber dan fasa penerima sesudah proses transpor ditentukan dengan SSA melalui metode Kurva kalibrasi. Pengukuran konsentrasi $\mathrm{Cu}$ (II) dilakukan pada $\lambda_{\text {maks }} 324,7 \mathrm{~nm}$. Kurva kalibrasi dibuat dari pengukuran absorban konsentrasi larutan standar 1,2,4,6,8, 10 dan 15 ppm. Dari hasil pengukuran, dibuat persamaan regresi linear $\mathrm{Cu}(\mathrm{II})$. Kurva kalibrasi di buat setiap kali pengukuran dan setiap kondisi percobaan. Dengan mensubtitusikan harga absorban ion sampel pada kurva kalibrasi standar, maka konsentrasi sampel dapat diketahui.

\section{Penentuan kondisi optimum tanspor $\mathrm{Cu}(\mathrm{II})$}

\section{Pengaruh pH fasa sumber (3 - 7)}

Sejumlah 0,0155 g APDC dipanaskan dalam akuades. Setelah dingin, larutan dimasukkan ke dalam labu $50 \mathrm{~mL}$ yang berisi $\mathrm{Cu}$ (II) $3,15 \mathrm{x}$ $10^{-4} \mathrm{M}$, lalu ditambahkan $\mathrm{HCl}$ 0,01 M untuk menurunkan $\mathrm{pH}$ dan ditambahkan larutan buffer asetat untuk menahan $\mathrm{pH}$, kemudian ditambahkan akuades sampai tanda batas. Variasi pH dilakukan pada daerah 3 - 7. Fasa membran $30 \mathrm{~mL}$ kloroform dan fasa penerima $12 \mathrm{~mL} \mathrm{H}_{2} \mathrm{SO}_{4} 1 \mathrm{M}$. Kemudian dilakukan proses transpor dan ditentukan konsentrasi $\mathrm{Cu}$ (II) pada masing-masing fasa.

\section{Pengaruh reagen penerima $\left(\mathrm{H}_{2} \mathrm{SO}_{4}, \mathrm{HCl}\right.$, dan $\mathrm{HNO}_{3}$ )}

Prosedur kerja sama dengan prosedur pengaruh $\mathrm{pH}$ fasa sumber, tetapi fasa sumber menggunakan $\mathrm{pH}$ optimum yang telah didapatkan. Sementara fasa penerima 
reagennya divariasikan yaitu $\mathrm{H}_{2} \mathrm{SO}_{4}, \mathrm{HCl}$, dan $\mathrm{HNO}_{3}$

\section{Pengaruh konsentrasi APDC}

Prosedur kerja sama dengan prosedur pengaruh fasa sumber, tetapi fasa sumber menggunakan $\mathrm{pH}$ optimum yang telah didapatkan. Sementara fasa penerima reagennya adalah reagen optimum yang didapatkan.

\section{Pengaruh konsentrasi reagen penerima (1 - $5 \mathrm{M})$}

Prosedur kerja seperti prosedur pengaruh fasa sumber, tetapi menggunakan $\mathrm{pH}$, reagen penerima dan konsentrasi APDC optimum dari prosedur sebelumnya.

\section{Pengaruh lama pengadukan ( 1 - 5 jam)}

Prosedur kerja seperti prosedur pengaruh fasa sumber, tetapi menggunakan kondisi optimum dari prosedur sebelumnya.

\section{HASIL DAN PEMBAHASAN}

\section{Pengaruh pH Fasa Sumber}

$\mathrm{pH}$ merupakan faktor yang sangat mempengaruhi interaksi $\mathrm{Cu}(\mathrm{II})$ dalam membentuk kompleks dengan APDC seperti reaksi di bawah ini. Pada $\mathrm{pH}$ yang tepat $\mathrm{Cu}(\mathrm{PDC})_{2}$ akan terbentuk dan terjadi ekstraksi $\mathrm{Cu}$ (II) dari fasa sumber ke fasa membran karena kompleks ini larut baik dalam pelarut organik dan selanjutnya distripping ke fasa penerima karena keberadaan asam sulfat.

$$
\begin{aligned}
& \left.\mathrm{Cu}\left(\mathrm{H}_{2} \mathrm{O}\right)_{4}{ }^{2+}{ }_{(\mathrm{f} . s}\right)+2 \mathrm{APDC}_{(\mathrm{f}, \mathrm{s})} \leftrightarrow \mathrm{Cu}(\mathrm{PDC})_{2(\mathrm{f} . \mathrm{m})} \\
& +4 \mathrm{H}_{2} \mathrm{O}_{\text {(f.s) }}+2 \mathrm{~A}^{+}{ }_{\text {(f.s) }} \\
& \mathrm{Cu}(\mathrm{PDC})_{2(\mathrm{f} . \mathrm{m})}+2 \mathrm{H}^{+}{ }_{(\mathrm{f} . \mathrm{p})} \rightarrow \mathrm{Cu}(\mathrm{II})_{(\text {f.p) }}+ \\
& 2 \mathrm{HPDC}_{(\mathrm{ffp})}+
\end{aligned}
$$

Kompleks $\mathrm{Cu}$ (II) dengan APDC ini merupakan kompleks tidak bermuatan dimana melalui kesetimbangan reaksi yang diatur sedemikian rupa melibatkan proses transpor $\mathrm{Cu}(\mathrm{II})$ dari fasa sumber ke fasa membran dan berlanjut ke fasa penerima.
Dari Gambar 1 dapat dilihat bahwa $\mathrm{Cu}$ (II) sudah banyak terekstrak ke fasa penerima pada daerah $\mathrm{pH} 3-6,5$ dan persentase $\mathrm{Cu}(\mathrm{II})$ yang terbesar di fasa penerima terjadi pada $\mathrm{pH} 4$ di fasa sumber yaitu $18,25 \%$ sedangkan persentase $\mathrm{Cu}(\mathrm{II})$ sisa di fasa sumber saat ini $81,58 \%$ sedangkan $\mathrm{Cu}(\mathrm{II})$ yang masih terperangkap di dalam fasa membran $0,17 \%$. Di sini dapat dilihat bahwa pada keadaan asam, kompleks $\quad \mathrm{Cu}(\mathrm{PDC})_{2} \quad$ mengalami kesetimbangan reaksi yang sangat baik untuk mentranspor $\mathrm{Cu}(\mathrm{II})$ karena keberadaan $\mathrm{H}_{2} \mathrm{SO}_{4}$ di fasa penerima. Tingginya kurva persentase $\mathrm{Cu}$ (II) yang tersisa di fasa sumber daripada yang tertranspor ke fasa penerima disebabkan masih belum sempurnanya pembentukan kompleks $\mathrm{Cu}$ (II) dengan APDC karena jumlah APDC yang tersedia di fasa sumber masih kecil sehingga tidak semua $\mathrm{Cu}(\mathrm{II})$ dapat diperangkap untuk membentuk kompleks dengan APDC. Bila $\mathrm{pH}$ fasa sumber semakin besar, maka $\mathrm{Cu}(\mathrm{II})$ mempunyai kecendrungan untuk memulai mengendap di fasa sumber sehingga persentase yang dihasilkan di fasa penerima menjadi turun.

\section{Pengaruh Jenis Reagen Fasa Penerima}

Jenis reagen penerima yang digunakan dipilih dari ketiga asam berikut yaitu $\mathrm{H}_{2} \mathrm{SO}_{4}, \mathrm{HCl}$ dan $\mathrm{HNO}_{3}$ dengan konsentrasi $1 \mathrm{M}$. Dari Gambar 2 dapat dilihat bahwa ketiga asam tersebut memenuhi untuk dipakai sebagai reagen penerima. Pada penelitian ini dipilih $\mathrm{HNO}_{3}$ sebagai fasa penerima karena asam ini relatif lebih tinggi mentranspor $\mathrm{Cu}$ (II) daripada asam yang lain $(19,30 \%)$. Dalam hal ini asam nitrat ternyata dapat menarik $\mathrm{Cu}$ (II) ke fasa penerima lebih baik dibandingkan dengan asam-asam yang lain. Hal ini disebabkan oleh karena asam nitrat di fasa penerima merupakan sumber proton yang kuat untuk memprotonasi pengompleks dan membebaskan $\mathrm{Cu}(\mathrm{II}) \mathrm{ke}$ dalam fasa penerima. $\mathrm{Cu}$ (II) yang tersisa di fasa sumber masih banyak, hal ini juga disebabkan oleh karena APDC yang digunakan untuk mengomplekskan $\mathrm{Cu}$ (II) masih sedikit sehingga persentase $\mathrm{Cu}$ (II) yang tersisa di fasa sumber tinggi. Pada kondisi ini, persentase $\mathrm{Cu}$ (II) sisa di fasa sumber sebesar $80,13 \%$ dan $\mathrm{Cu}(\mathrm{II})$ yang masih terperangkap di dalam fasa membran $0,57 \%$. 


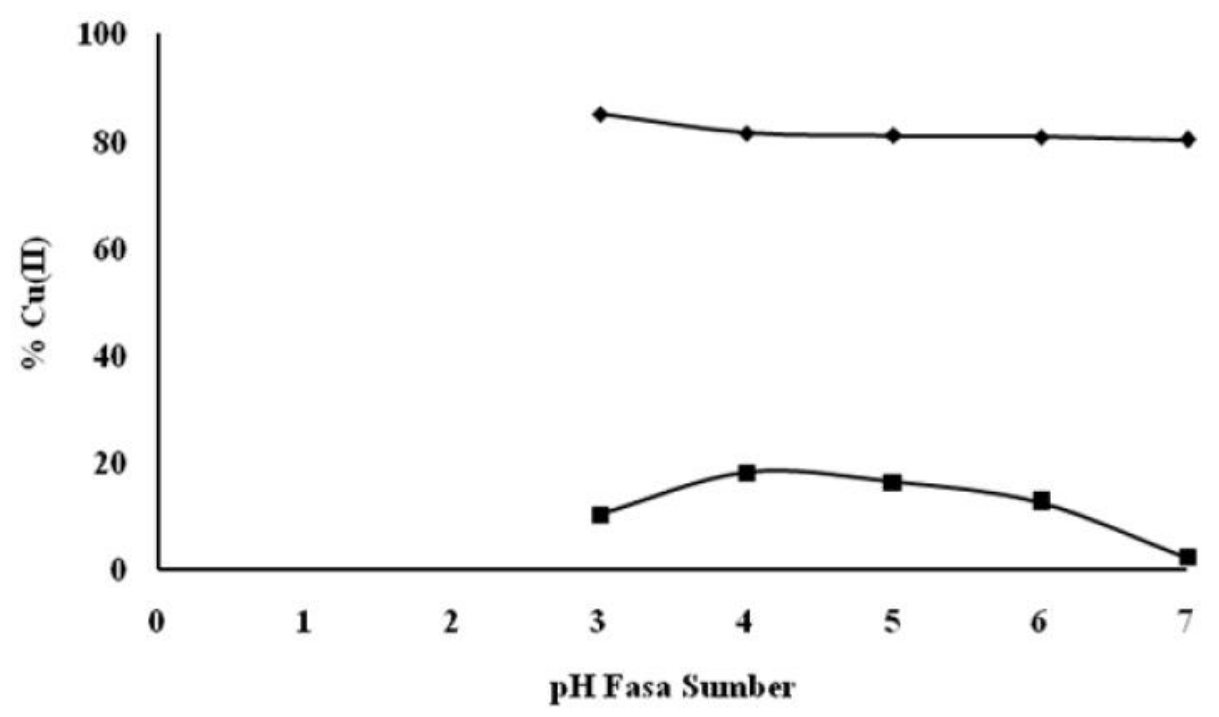

Gambar 1. Pengaruh pH terhadap jumlah $\mathrm{Cu}$ (II) ke fasa penerima ( $\mathbf{\square}$ ) dan sisa $\mathrm{Cu}$ (II) dalam fasa sumber (

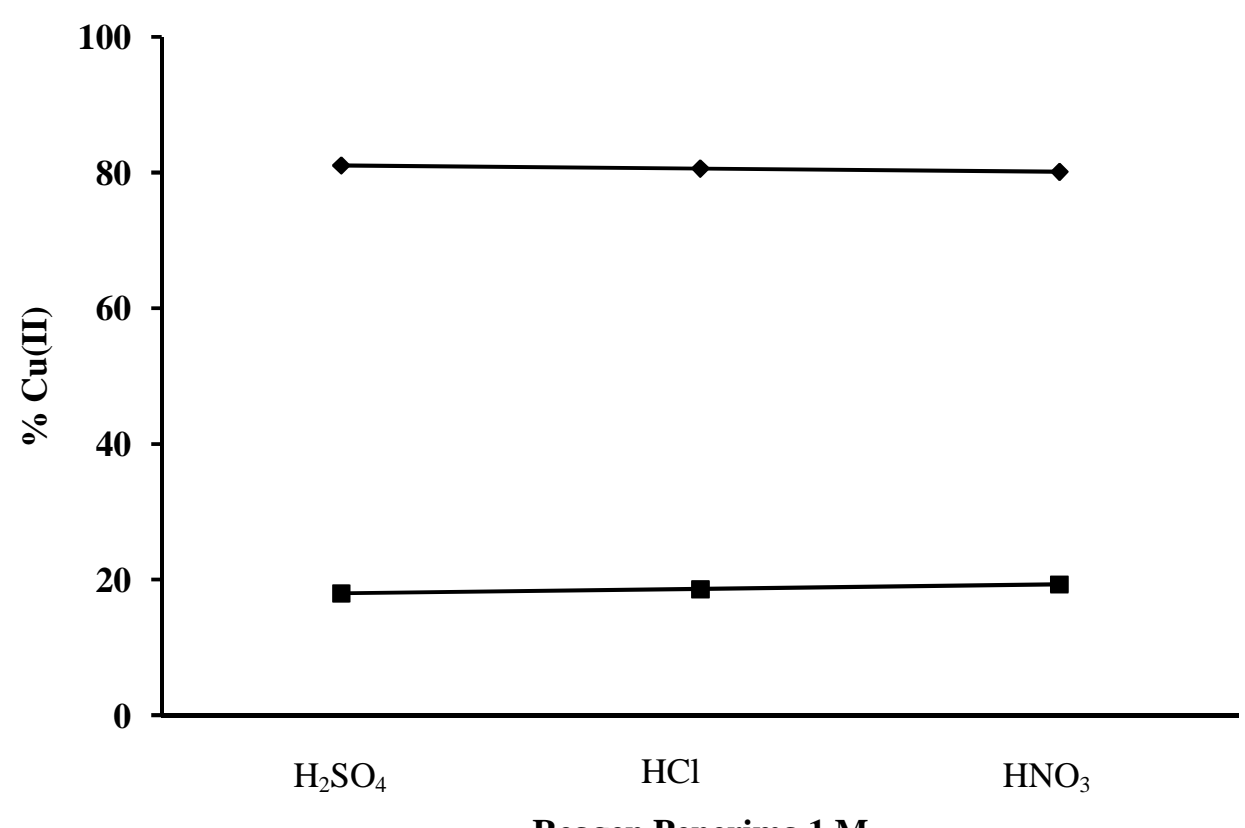

\section{Reagen Penerima $1 \mathrm{M}$}

Gambar 2. Pengaruh jenis reagen fasa penerima pada transpor $\mathrm{Cu}(\mathrm{II})$

\section{Pengaruh Konsentrasi APDC}

APDC merupakan senyawa pengompleks, dapat digunakan untuk mengekstrak ion-ion logam dalam larutan. Kompleks ion logam dengan senyawa ini merupakan kompleks yang tidak bermuatan sehingga larut baik dalam pelarut organik. Daerah $\mathrm{pH}$ kestabilannya yang cukup besar dalam membentuk kompleks dengan banyak ion-ion logam maka senyawa ini sering dipakai dalam sistem ekstraksi untuk memisahkan ion-ion dari dalam larutan berair. Di sini APDC digunakan sebagai zat pembawa untuk mentranspor $\mathrm{Cu}$ (II) dari fasa sumber ke fasa membran melalui proses reaksi pengomplekskan dengan cara menginteraksikan $\mathrm{Cu}(\mathrm{II})$ sebagai sampel dan APDC sebagai zat pembawa di fasa sumber pada perbandingan $1: 6 \mathrm{~s} / \mathrm{d} 1: 32$. 
Dari Gambar 3 dapat dilihat bahwa APDC sebagai zat pembawa mampu meningkatkan transpor $\mathrm{Cu}$ (II) ke fasa penerima dan mencapai optimum pada perbandingan $\mathrm{Cu}$ (II) dengan APDC sebesar 1 : 30. Pada kondisi ini persentase $\mathrm{Cu}(\mathrm{II})$ yang diperoleh difasa penerima adalah $35,29 \%$, dimana $\mathrm{Cu}$ (II) tidak terdeteksi lagi di fasa sumber. Dalam kasus ini $\mathrm{Cu}$ (II) banyak yang terperangkap di dalam fasa membran, yaitu sebesar $64,71 \%$. Jumlah ini akan makin meningkat jika perbandingan dinaikkan menjadi 1 : 32, maka didapatkan persentase $\mathrm{Cu}(\mathrm{II})$ di fasa penerima turun menjadi $0,73 \%$ dan yang terperangkap dalam membran naik menjadi 99,27\%. Hal ini disebabkan kompleks $\mathrm{Cu}(\mathrm{PDC})_{2}$ yang terbentuk sangat stabil sehingga banyak terperangkap dalam fasa membran dan sulit ditarik oleh $\mathrm{HNO}_{3}$ ke fasa penerima.

\section{Pengaruh konsentrasi $\mathrm{HNO}_{3}$ di fasa penerima}

Untuk meningkatkan sistem transpor $\mathrm{Cu}$ (II) ke fasa penerima, konsentrasi $\mathrm{HNO}_{3}$ di fasa penerima merupakan faktor yang ikut mempengaruhi transpor ion logam. Disini $\mathrm{HNO}_{3}$ dipakai sebagai reagen penerima, berfungsi menarik ion $\mathrm{Cu}$ (II) yang ada di fasa membran agar sampai ke fasa penerima melalui proses reaksi protonasi asam terhadap kompleks $\mathrm{Cu}(\mathrm{PDC})_{2}$ di antarmuka fasa membran dengan fasa penerima. Interaksi ini akan makin bertambah kuat sesuai dengan kekuatan dan konsentrasi asam yang dipakai di fasa penerima. Peningkatan konsentrasi $\mathrm{HNO}_{3}$ yang dipakai sebagai reagen penerima untuk proses reaksi protonasi ini dilakukan dengan memvariasikan konsentrasi $\mathrm{HNO}_{3}$ dari $1 \mathrm{M}$ sampai $5 \mathrm{M}$. Pengaruh yang berarti dapat dilihat dari Gambar 4.

Gambar 4 memperlihatkan bahwa semakin tinggi konsentrasi asam nitrat maka transpor $\mathrm{Cu}$ (II) ke fasa penerima juga semakin meningkat sampai mencapai optimum pada konsentrasi asam nitrat $4 \mathrm{M}$, dengan $\mathrm{Cu}$ (II) yang diperoleh saat itu sebesar 93,35\% dan konstan dengan peningkatan konsentrasi lebih lanjut. Hal ini disebabkan karena dengan semakin tinggi kekuatan proses protonasi, maka kesetimbangan reaksi yang terjadi pada kompleks $\mathrm{Cu}(\mathrm{PDC})_{2}$ di antarmuka fasa membran dengan fasa penerima lebih cendrung ke arah pelepasan $\mathrm{Cu}(\mathrm{II})$ sehingga meningkatkan transpor $\mathrm{Cu}(\mathrm{II})$ ke fasa penerima. Pada kondisi ini, $\mathrm{Cu}(\mathrm{II})$ tersisa di fasa sumber tidak terdeteksi dan yang masih terperangkap di fasa membran $5,12 \%$.

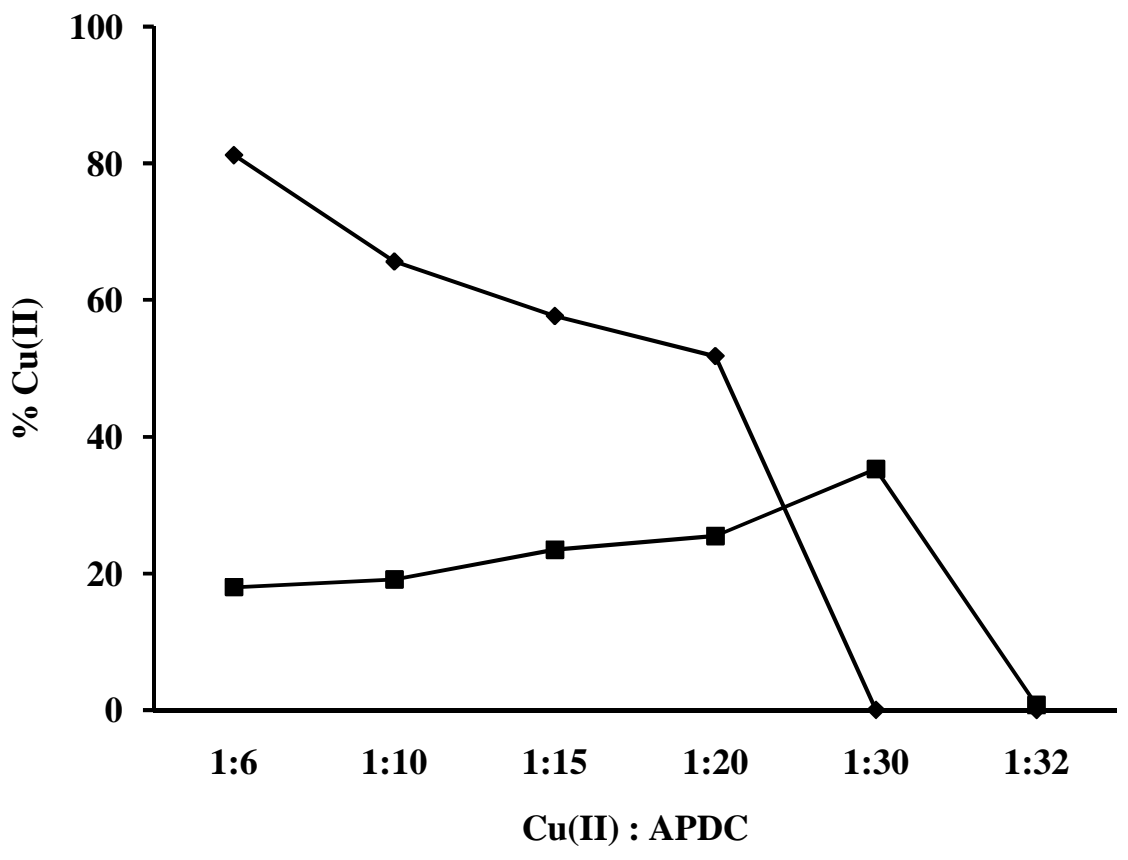

Gambar 3. Pengaruh variasi konsentrasi APDC terhadap jumlah $\mathrm{Cu}$ (II) 


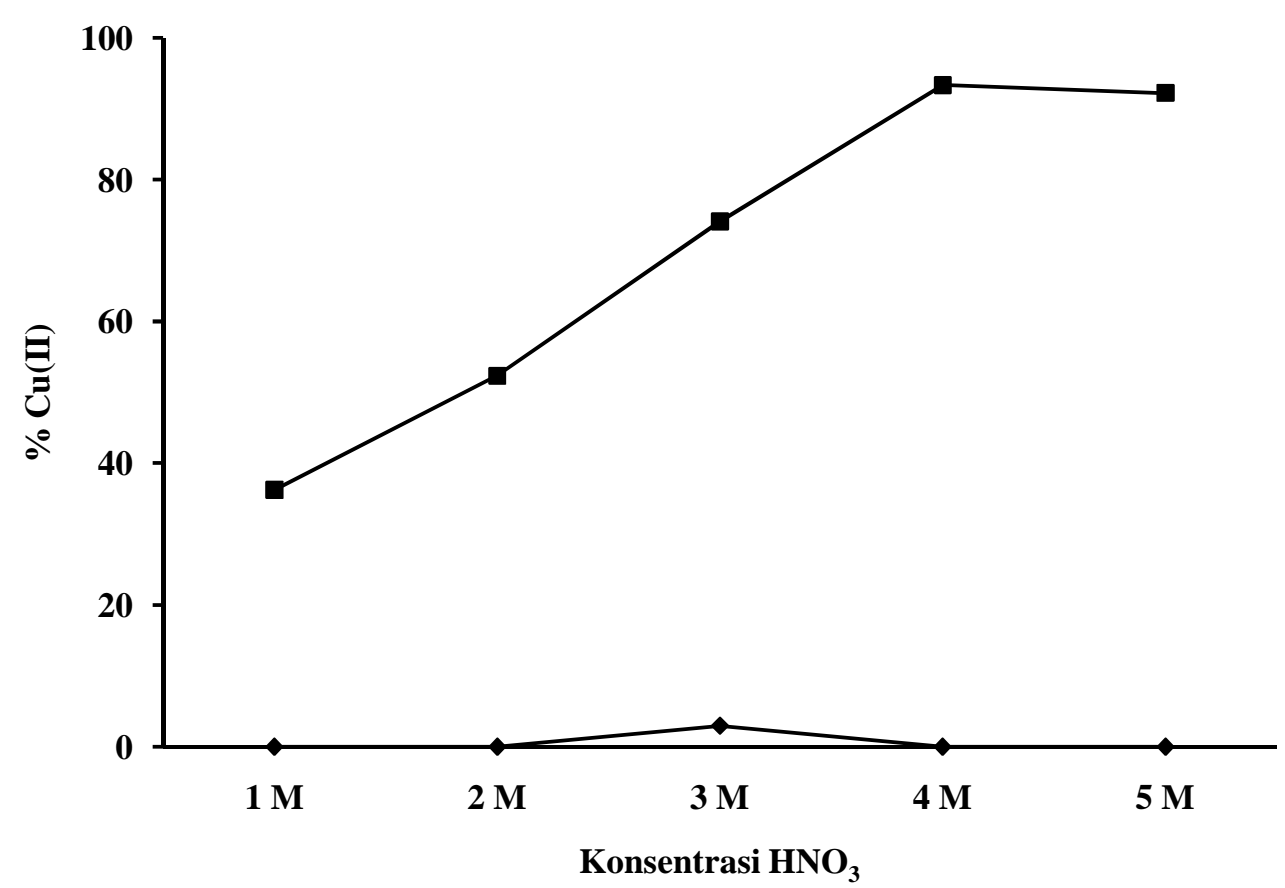

Gambar 4. Pengaruh konsentrasi $\mathrm{HNO}_{3}$ terhadap terhadap transpor $\mathrm{Cu}$ (II)

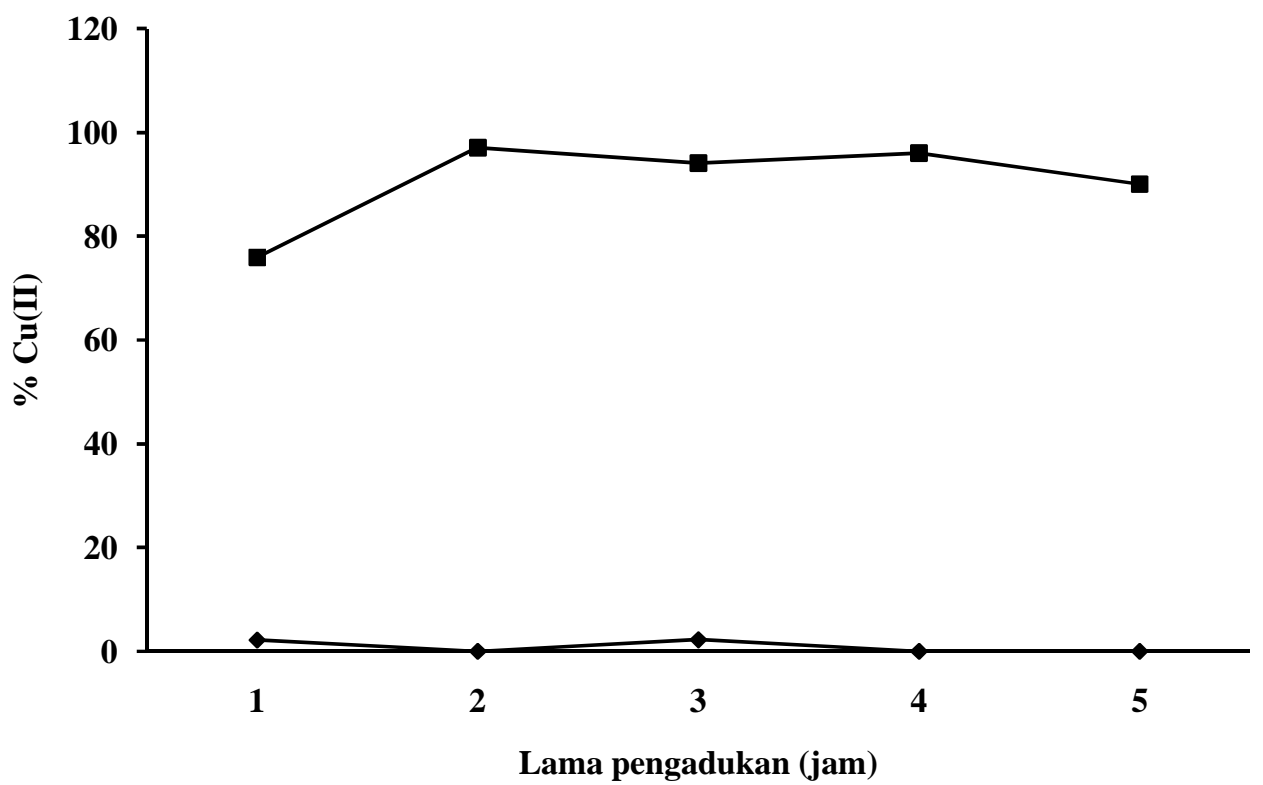

Gambar 5. Pengaruh lama pengadukan terhadap transpor $\mathrm{Cu}(\mathrm{II})$ dari fasa sumber ke fasa penerima

\section{Pengaruh Lama Pengadukan}

Lama pengadukan sangat mempengaruhi proses transpor yang terjadi dari suatu ion logam karena faktor pengadukan sangat mempengaruhi interaksi tumbukan antar molekul dalam memperlancar terjadinya proses difusi. Untuk meningkatkan sistem transpor $\mathrm{Cu}(\mathrm{II})$ antar fasa, lama pengadukan divariasikan dari 1 sampai 5.
Gambar 5 menunjukkan hubungan antara lama pengadukan terhadap persentase transpor $\mathrm{Cu}(\mathrm{II})$ melalui membran cair fasa ruah setelah kondisi optimum dengan konsentrasi $\mathrm{Cu}$ (II) di fasa sumber 3,15 x $10^{-4}$ M. Dengan bertambahnya waktu pengadukan maka akan meningkatkan persentase transpor $\mathrm{Cu}$ (II) ke fasa penerima sampai mencapai waktu transpor optimum pada 2 jam dan konstan dengan peningkatan lama pengadukan. Persentase 
transpor $\mathrm{Cu}$ (II) di fasa penerima sebesar $97,06 \%$. Sedangkan persentase $\mathrm{Cu}(\mathrm{II})$ sisa di fasa sumber tidak terdeteksi. Sisanya masih terperangkap di dalam fasa membran $2,94 \%$. Kondisi ini merupakan kondisi optimum dari sistem transpor $\mathrm{Cu}$ (II) dengan menggunakan APDC sebagai zat pembawa melalui teknik membran cair fasa ruah.

\section{KESIMPULAN}

Berdasarkan penelitian yang telah dilakukan maka dapat disimpulkan bahwa spesifikasi transpor $\mathrm{Cu}$ (II) dengan konsentrasi 3,15 x $10^{-4}$ $M$ menggunakan APDC sebagai zat pembawa dapat diperoleh melalui teknik membran cair fasa ruah. Kondisi optimum dari transpor $\mathrm{Cu}$ (II) antar fasa melalui metoda ini adalah $\mathrm{pH}$ fasa sumber 4, perbandingan konsentrasi $\mathrm{Cu}$ (II) dengan APDC dalam fasa sumber 1 : 30, konsentrasi $\mathrm{HNO}_{3} 4 \mathrm{M}$ untuk fasa penerima, dan lama pengadukan 2 jam. Pada kondisi ini didapatkan persentase transpor $\mathrm{Cu}$ (II) ke fasa penerima $97,06 \%\left(1,53 \times 10^{-4}\right.$
M), persentase $\mathrm{Cu}$ (II) tersisa di fasa sumber tidak terdeteksi, dan persentase $\mathrm{Cu}$ (II) yang masih terperangkap di fasa membran $2,94 \%$.

\section{DAFTAR PUSTAKA}

1. M. Molina, L. Arenas, Viotoria, and J. A. Ibanes, Characterization of membrane system. complexes character of permeability from an electrical model, $J$. Phys. Chem., 101: 10323-10331,(1997).

2. M. Mulder, Basic principle of membrane technology, Kluwer Academic Publisher, Dordrecht. Pp. 244-259. 1991.

3. O. N. Tetra. Transpor antar fasa dari ion tembaga (II) melalui membran cair fasa ruah, Padang: UNAND, 2001.

4. Yathi dan U. Hasanah, Ekstraksi Ion Fe (III) dengan ekstraktan APDC dalam MIBK, Semarang: FMIPA. 2006.

5. H. G. Morrison and F. Hendry, Solvent extraction indonesia analytical chemistry. Jhon Whilley and Son, 10-15, 1957. 